\title{
Suffering in the mystical traditions of Buddhism and Christianity
}

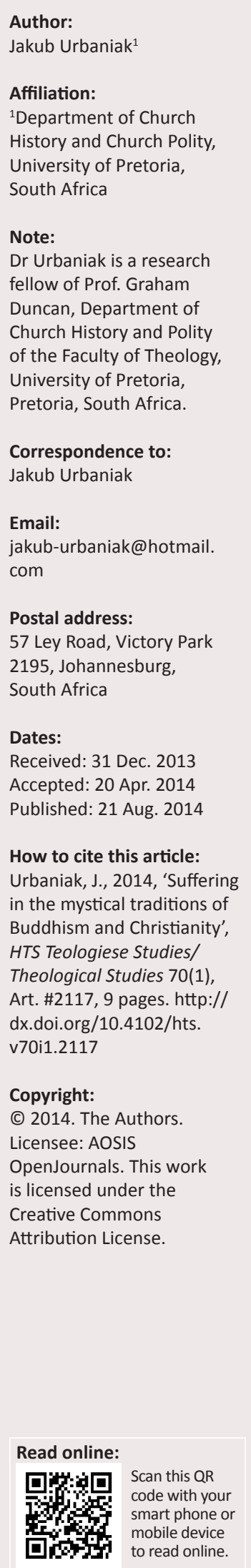

This article seeks to explore the mystical approaches to suffering characteristic of both Buddhism and Christianity. Through the analysis of the meanings, the two traditions in question ascribe to suffering as a 'component' of mystical experience; it challenges the somewhat oversimplified understanding of the dichotomy 'sage-the-robot versus saint-the-sufferer'. Thus it contributes to the ongoing discussion on the theological-spiritual dimensions of the human predicament, as interpreted by various religious traditions. It also illustrates (though only implicitly) in what sense - to use the Kantian distinction - the mystical experience offers boundaries (Schranken) without imposing limits (Grenzen) to interfaith encounter and dialogue.

Man [sic] is ready and willing to shoulder any suffering, as soon and as long as he can see a meaning in it. (Frankl 1967:56)

\section{Introduction}

Throughout the ages, religions and philosophical systems have formulated a myriad of explanations of the human predicament. Buddhism looks at our existential situation mainly through the prism of a concrete experience marked by a common painfulness: a burden from which a human being should simply be liberated. Christian faith interprets it in reference to God's plan regarding humanity: the plan spoiled (and being spoiled continuously) by human sin but ultimately accomplished by Jesus-the-Son.

For Buddhism dukkha is simply a 'state' of all living beings; suffering - in all its aspects - is identified with existence. Therefore, the only positive meaning of suffering a Buddhist can be interested in is its didactic meaning (i.e. the experience of suffering as a motivation to follow the Dharma). As for the Christian passio, one has to distinguish between what is in a certain sense inscribed into God's vision of creation, and what - being the result of sin - is actually a curse that humanity has brought (and is still bringing) on itself by misusing its freedom. In view of that distinction, eliminating or overcoming every form of pain certainly cannot be considered the superior aim of a religious practice. A Christian ought rather to accept the mysterious character of suffering and be able to assume an adequate attitude depending on circumstances: the particular manifestations of suffering should be surrounded by compassion and possibly relieved, whilst trying to regard those which evade human forces as 'good in time', and to bear them in unity with Christ dead and risen.

The French philosopher Gabriel Marcel, one of the leading Christian existentialists of the last century, made a significant distinction between problem and mystery. Put simply, unlike problems which can be explained exhaustively and solved once and for all, mystery does not allow easy solutions. As Marcel (1949) explains:

Mystery is something in which I am myself involved, and it can therefore only be thought of as a sphere where the distinction between what is in me and what is before me loses its meaning and initial validity. (p. 117)

In light of Marcel's distinction, it can be assumed that for Buddhism suffering ( $d u k k h a)$ constitutes an original fact and the universal problem of humankind which needs to be understood (illusion and desire as the sources of $d u k k h a$ ) and then practically solved (liberation). For Christianity, in turn, suffering is most of all a mystery, at least to some extent rooted in mysterium iniquitatis - a mystery whose salvific sense is to be found by a personal participation in passio Christi.

However, despite this general categorisation which emerges from the doctrinal understandings of suffering in Buddhism and Christianity, a number of rather surprising approaches may be found in both traditions. These approaches, though seemingly exceptional, bring an essential novelty to the panorama of religious meanings ascribed to suffering. My thesis is that these subtleties become most visible and graspable in the field of mystical traditions of Buddhism and Christianity. 
This article is arranged in two sections. Firstly, I will show how the mystical approaches to suffering characteristic of Buddhism differ from those which can be found in Christianity. Secondly, through the more nuanced analysis of the meanings these two traditions ascribe to suffering as a 'component' of mystical experience, I will challenge the somewhat oversimplified understanding of the dichotomy 'sage-the-robot versus saint-the-sufferer'. ${ }^{1}$

My underlying intention is to contribute to the ongoing discussion on the theological-spiritual dimensions of the human predicament, as interpreted by various religious traditions. Through my critical examination of the meanings of suffering inherent in the mystical traditions of Buddhism and Christianity, I will also attempt to illustrate (though only implicitly) in what sense the mystical experience offers boundaries (Schranken) without imposing limits (Grenzen) to interfaith encounter and dialogue (Kant [1781] 2002:142).

\section{Saint and sage: The two models of mysticism}

What first grips our attention when we look at Buddhism and Christianity is the distance which divides (in almost every respect) Banaras from Jerusalem. Spelled out briefly, within the general category of religion:

Buddhism and Christianity appear to occupy opposite poles: over against a religion of enlightenment, a religion of faith; on the one hand a religion of experience, on the other a religion of dogma; a religion of wisdom facing a religion of love; a religion centred on the human self over against a religion centred on God; on the one hand, a religion of introversion and equanimity and on the other, a religion of extraversion and desire. (Mommaers \& Van Bragt 1995:28)

What is more, the teaching of multiple Buddhist traditions and schools is considerably more varied than in the case of Christian denominations and churches; indeed, the univocal criterion for determining what is 'Buddhist' and what is not is a point of argument. Needless to say, this ambiguity makes talking about Buddhism in general very problematic (Hubbard \& Swanson 1997). ${ }^{2}$ And yet for the sake of my study, I must venture that methodologically challenging perspective so that the wide scope of mystical meanings ascribed to suffering by the diverse forms of Buddhism can be captured. ${ }^{3}$

It seems that in the face of this doctrinal diversity (both on the inter- and intra-religious plane), mysticism can offer, if not a common denominator, at least a possible platform for dialogue. However, also in this regard one is confronted with the bewildering variety of interpretations of mysticism in

1.As will become clear throughout my study, I refer to those two 'caricature-figures' of Buddhist wisdom and Christian sanctity in order to call into question the apparently unbridgeable gap between Buddhist detachment from any suffering-generating aspects of existence, on the one hand, and Christians voluntarily plunging into suffering and ascribing to it salvific meaning, on the other.

2.'A bewildering variety of religious forms has grown out of the Buddha's teaching, such a variety in fact that at times their common root is barely visible' (Küng et al. 1986:361)

3.I attempt to deal with that challenge by adequately qualifying generalised statements regarding both Buddhism and Christianity; usually the relevant caveats are included in the footnotes. general and mystical experience in particular - of its nature and the role it plays within religious experience broadly understood. For the purpose of my study, I adopt the Routledge encyclopaedia of philosophy's definition of mysticism, namely, 'a form of consciousness involving an apparent encounter or union with an ultimate order of reality, however it is understood' (Craig 1998:620).

In light of this working definition of the term, one cannot fail to notice that Buddhism and Christianity are not 'mystical' in the same sense and to the same degree. The Buddhist approaches reality precisely through the 'silent non-rational path of mysticism' (Stevens 1973:97-98). ${ }^{4}$ In other words, mysticism is congenial to the Buddhist way of thinking and practical for the Buddhist way of living (Stevens 1973:161). ${ }^{5}$ Christianity instead, as a prophetic religion, has never made mysticism central and essential to salvation, although it developed its own rich mystical traditions. ${ }^{6}$ That being said, I can now turn to the issue of suffering.

At first glance, the experience of suffering plays totally different roles within each of the two mystical traditions in question. On the one hand, a Buddhist sage, not attached to favourable conditions and not repelled by unfavourable ones, seeks first and foremost liberation from suffering. Even when afflicted with bodily pain, he or she endures such a feeling patiently, with equanimity, as for him or her $d u k k h a$ is nothing but an external object of contemplation (Bodhi 2005:21). As D.T. Suzuki (2002:113) accurately puts it, in Buddhism 'there is no ego to be crucified'. On the other hand, looking at the writings of great Christian saints one may reach a conclusion that an intense experience of suffering is a sine qua non condition of being a Christian mystic. ${ }^{7}$ The Cross seems to be the only way of uniting with Christ, which is so impressively reflected in the cry usually inscribed as a motto upon images of Teresa of Avila (1957:312), 'Lord, either let me suffer or let me die!' (author's paraphrase).

This gives us two contrasting images of mystical experience with regard to suffering. Emile Cioran (1970), a 20th century Romanian existentialist who spent most of his adult life in Paris writing rather pessimistic and yet surprisingly stimulating aphoristic texts, achieved a real mastery in stressing this contrast:

After twenty centuries in which convulsion was regarded as a sign of spiritual advancement ... accustomed to a racked, ruined, grimacing Saviour, we are unsuited to enjoy ... the inexhaustible smile of a Buddha plunged into a vegetable beatitude. (p. 139)

4.'Buddhism is a mystical religion with mysticism's mistrust of words' (Stevens 1973:105).

5.See also Mommaers and Van Bragt (1995:31-32), where the author ponders whether it makes sense to speak of a 'Buddhist mysticism'.

6.Needless to say, the Eastern Orthodox churches generally ascribe a greater significance to the mystical component of religious theory and praxis than the Western churches, especially those that have emerged from the Reformation.

7.Such an impression should not, however, be followed by the claim that Christian mystical experience is unthinkable without a direct reference to suffering. Bernard McGinn's (1996:x-xi) definition of Christian mysticism rightly situates the core of mystical experience in 'an immediate or direct presence of God'. And yet the fact mystical experience in 'an immediate or direct presence of God'. And yet the fact by that of Christ's passion. 
Such a caricature and hyperbole of Western (Christian) and Eastern (Buddhist) attitudes towards suffering may of course be reproached for being too simplistic. Nonetheless, it rightly indicates the two opposed tendencies represented by the passionate saint eagerly plunging into suffering and the indifferent monk detached from all earthly miseries.

However, stopping at this stage, that is, confronting 'sage-the-robot' with 'saint-the-sufferer', (or even 'saintthe-masochist') would be a serious mistake. This scheme can be challenged by numerous testimonies of mystics, both Buddhist and Christian. Taking this diversity into account is critical for understanding how suffering is embraced and integrated in the two mystical traditions under discussion.

\section{'No ego to be crucified': Mysticism as uprooting suffering}

In Theravāda, with its ideal of the arhat [enlightenment in Buddhist terms], no positive meanings are attributed to suffering except for its didactic function. In consequence, from the point of view of the early Buddhism, a monk voluntarily plunging into suffering or ascribing some positive senses to it would have to be seen as a 'mystical failure'. At the same time, in Buddhism as such, and particularly in its oldest forms, the suffering and transiency of the world constitute the object of contemplation par excellence (Mommaers \& Van Bragt 1995:37). In this sense, being the result of our own negative past actions, dukkha is also seen as an effective 'catalyst for seeking spiritual liberation' (Dalai Lama \& Cutler 1998:168). Meditation on suffering is a fundamental way of uprooting it. Indeed, enlightenment itself is a fruit of prajñ $\bar{a}$, clear insight into the Four Noble Truths about the 'inconvenience of being'.

The first three Noble Truths give the disease, the cause, and the cure, whereas the fourth one is to be conceived of as the doctor's prescription. And it is at this point that the Buddhist mystical practice has its essential role to play. The Eightfold Noble Path to Enlightenment, indicated by the fourth Noble Truth, constitutes a 'manual for the practice of the Middle Way' (Stevens 1973:106). The first two steps call for commitment:

- right understanding

- right attitude of mind.

The following three indicates that understanding and consequent commitment must translate into action, that is, find their expression in a moral attitude:

- right speech

- right action

- right livelihood.

Finally, the last three cover the mystical dimensions of the Dharma:

- right effort

- right awareness

- right concentration.
In fact, both commitment and moral action merely prepare the human person for meditation which is, without doubt, the highest form of the Buddhist practice (Stevens 1973:106-107).

A double movement is to be found within Buddhist mystical practice: on the one hand, there is the doctrine of anatta [No-Self], on the other, the discovery of one's Buddha-nature (Stevens 1973:163). They can be seen as the two sides of the same experience in which the monk-mystic overcomes dukkha by meditating on it and, ultimately, by realising that there is no personal subject such as ' $\mathrm{I}$ ', or 'you', thereby suffering lacks in sufferer. One ought to remember that in Buddhism meditation does not mean rational analysis. For the mystic, existential problems such as death, suffering, failure or frustration are not to be rationally solved, but rather 'transrationally dis-solved' (Stevens 1973:170). It is underscored especially in Zen Buddhism that Bodhi [awakening] is not to be attained by any particular effort. The monk must only allow the 'flame of existence' to be extinguished. As one of the Zen koans says: 'Sitting quietly, doing nothing, spring comes, and the grass grows by itself' (Stevens 1973:45).

One might ask whether individual human death and suffering, experiences belonging to the realm of samsara and maya [illusion] matter, if the human person is already liberated. As for the suffering, it does not affect an enlightened one in the same manner as it does the average person. The worldling reacts to all objective aspects of suffering, and therefore, on top of painful bodily feelings, he or she experiences also painful mental feelings including sorrow, resentment, distress, and so forth (Dalai Lama \& Cutler 1998:116). In contrast to that, anyone who has discovered the emptiness (the lack of self) of all things is thus able to reduce the suffering resulting from pain to its elementary, strictly bodily aspect. Also death loses its common meaning. Even though the liberated one is subject to physical death (as the Buddha himself was) he or she is no longer in its power, for in his or her case death leads not to rebirth in a next existence but directly to Nirvana:

The Buddha did not die! The Arhats ... do not die! They don't die as people and animals do ... Earth, water, fire, air - the four elements simply split up; there is no person in these things ... Dirt, they call it. A pile of dirt! By seeing that there are only earth, water, fire, and air, they conquer death. (Gyatso 1994:74-75)

In his famous (and widely criticised) book Mysticism: Christian and Buddhist (2002), Suzuki discusses the Buddhist 'spirituality of suffering' as contrasted with the Christian one:

Christian symbolism has much to do with the suffering of man [sic]. The crucifixion is the climax of all suffering. Buddhists also speak much about suffering and its climax is the Buddha serenely sitting under the Bodhi tree ... Christ carries his suffering to the end of his earthly life, whereas Buddha puts an end to it while living and afterwards goes on preaching the gospel of enlightenment until he quietly passes away under the twin Sala trees ... What a contrast between the crucifixion-image of Christ and the picture of Buddha lying on a bed surrounded by his disciples and other beings non-human as well as human! (pp. 117, 120) 
As Suzuki (2002:117) explains, the sight of Christ hanging 'helpless, full of sadness on the vertically erected cross' is almost unbearable to the Oriental mind. ${ }^{8}$ Why? Because by elevating the Cross to the level of God's central Revelation, Christianity makes the human person combative: it encourages us to crucify 'the self' because it is considered to be the threatening enemy:

Christians would say that crucifixion means crucifying the self or the flesh, since without subduing the self we cannot attain moral perfection. This is where Buddhism differs from Christianity. Buddhism declares that there is from the very beginning no self to crucify... As there is no self, no crucifixion is needed, no sadism is to be practiced, no shocking sight is to be displayed by the road-side. ${ }^{9}$ (Suzuki 2002:119-120)

\section{'To suffer or to die': Mystical elevation of suffering}

It has to be stressed that the very concept of suffering as a component of the mystical path differs significantly according to particular currents of Christian mysticism. For instance, Meister Eckhart's (Harmless 2008:107-134) focus is on the state of detachment understood as complete self-abandonment, and thus his approach is almost purely intellectual and metaphysical (Davies 1991:170). Julian of Norwich, on the other hand, describes her relation with Jesus in a very imaginative and affective way, emphasising the Lord's humanity and the bodily aspect of his and her own sufferings; the vividness of her visions is most impressive (Mommaers 2003:50). Teresa of Avilla, in turn, tends to meditate on Jesus' passion, so to say, looking down on it 'from the blissful height of "perfect contemplation"' (Mommaers 2003:72) as though all images and intermediaries (the Christ's humanity included) had been a kind of necessary evil but also a necessary condition of unio mystica (Mommaers 2003:72-73).

Suffering is first of all present in the experience of Christian mystics as a topic of visions and apparitions as well as a theme or image stimulating and nourishing their contemplation; in this case, it is about the suffering of Christ and, sometimes, the fellow-suffering of Mary. There is probably no religious event more likely to fill and fix a mystic's imagination and affection than what happened on the Via Dolorosa and on the hill of Calvary (Mommaers 2003:105). This Christocentrism is to be considered the central characteristics of Christian mystical experience. ${ }^{10}$

For instance, Julian of Norwich (c. 1342 - c. 1416) (Mommaers 2003:44-58) prayed for the grace of the 'painful

8. The crucified Christ is a terrible sight and I cannot help associating it with the sadistic impulse of a physically affected brain ... Christianity tends to emphasize the corporeality of our existence. Hence its crucifixion, and hence also the symbolism of eating the flesh and drinking the blood. To non-Christians, the very thought of drinking the blood is distasteful' (Suzuki 2002:120).

9.'When you clearly perceive that this deadly enemy who keeps you on the alert is non-existent, when you understand that it is no more than a nightmare, a mere delusion to posit a self as something trying to overpower you, you then will be delusion to posit a self as something trying to overpower you, you then will be
for the first time at peace with yourself and also with the world at large' (Suzuki 2002:121).

10.There are only a few exceptions in this regard; for example, Pseudo-Dionysius the Areopagite or Meister Eckhart, with his mystical focus on God and the Godhead. bodily presence of Jesus': 'I longed to be shown him in the flesh so that I might have more knowledge of our Saviour's bodily suffering' (Colledge \& Walsh 1978:286). And indeed in her 'showings', Julian very often saw Jesus' passion. In chapter 16, his body hanging on the cross is shown as slowly drying out; in her first Revelation, in turn, she describes 'the red blood trickling down from under the crown of thorns, hot and fresh and very plentiful' (Colledge \& Walsh 1978:294); elsewhere, we read about hot blood running out so abundantly that no skin or wound could be seen, and so forth.

The passion of Christ does not, however, capture the mystic's attention to keep it on itself; the ultimate aim of the contemplation on Jesus' one-time suffering in Jerusalem is to realise his actual suffering in the mystic himself or herself, here and now. In other words, the mystics are not satisfied with the mere visions of a suffering Christ, their appetites are bigger: they long for the active participation in his salvific passion. Let us look again at Julian's wishes:

That my whole body should be filled with remembrance and feeling of his blessed Passion; for I wanted his pains to be my pains, with compassion, and then longing for God ... I wanted to suffer with him. (Colledge \& Walsh 1978:292)

As for Bernard of Clairvaux (1090-1153) (Harmless 2008:41-58; Mommaers 2003:117-129), although he makes heartfelt love of and for Christ the hub of his spirituality, suffering still plays an essential role in his mystical experience. It is so because the main reason for loving the incarnate God is, for him, 'the price for our redemption' (Bernard of Clairvaux 1971:148). What moves, arouses, and enflames Bernard, making him love Jesus more than all the rest, is precisely the chalice that the Saviour drank for our salvation.

In addition, Francis of Assisi (1182-1226) (McGinn 2006: 225-230; Mommaers 2003:142-157) experienced suffering as a meaningful reality, integral for his mystical path. Francis, for whom the conformitas Christi indicated the lifetime spiritual programme, experiences Christ's crucifixion in his very own body (stigmata) and soul, so as to be 'totally transformed into the likeness of Christ crucified' (Bonaventure 1978:306), so as to bear with him 'the image of the Crucified ... engraved in the members of his body' (Bonaventure 1978:306). Jacopone da Todi (1230-1306), a Franciscan friar from Umbria, summarises his mystical experience as follows:

Therefore I suffer to see Your wounded heart.

Why did You endure the pain?

So that I might be healed. (Harvey 1996:195)

Teresa of Avila (1515-1582) (Mommaers 2003:59-94), one of the most striking personalities in the history of Christian spirituality, was not only graced with an 'overwhelming and multi-faceted mystical experience' (Mommaers 2003:59), but also had great talent for expression. In one of her spiritual texts, Teresa describes the Cherubim who thrusts a long spear of gold into her heart and leaves her all on fire with a great love of God. 'The pain was so great' - the Spanish saint 
says - 'that it made me moan; and yet so surpassing was the sweetness of this excessive pain that I could not wish to be rid of it' (Harvey 1996:195).

In his journal, Father Seraphim Rose (1934-1982), an American hieromonk of the Russian Orthodox Church, wrote:

Let us not, who would be Christians, expect anything else from it than to be crucified. For to be a Christian is to be crucified ... We must be crucified personally, mystically; for through crucifixion is the only path to resurrection. (Monk Damascene n.d.)

Last but not least, according to Thomas Merton (1915-1968) (Harmless 2008:19-40), the entire sense of Christian asceticism is summed up in Mark 8:34, when Jesus said, '[i]f any of you want to be my followers, you must forget about yourself. You must take up your cross and follow me' (Bailey 1975:79).

The common denominator is to be found, again, in a radical Christocentrism of mystical experience in the shape given to it by Christian saints. Christ's suffering within the mystic's personal experience appears as tantamount to the mystic's own suffering as a voluntary participation in the death and resurrection of the Saviour (Mommaers 2003:105). As Maria Petyt (1623-1677), the rather unknown Flemish mystic, puts it:

The soul does not perceive or feel her abandonment and pains as being in her, but she regards, loves, and embraces them as the pains of Christ with whom she is united, and at that moment she is also forgetting herself. (Mommaers 2003:105)

I chose these few examples to illustrate the elevation of suffering in the Christian mystical traditions. However, even whilst glancing through such testimonies one can already sense that they are not about the physical pain in and for itself; indeed, much more is at stake. That is why in due course I am going to reinterpret the aforementioned examples to articulate the meaning of suffering in Christian mystical traditions in a more integral and holistic manner.

\section{Transforming dukkha?}

Unlike Theravāda, Mahāyāna Buddhism developed a more subtle attitude toward suffering, integrating it, to a higher extent, in its mystical experience. First of all, as the Dalai Lama argues, from the pragmatic point of view:

Intentional contemplation of the suffering's nature ahead of time - in the sense of developing greater acceptance of suffering as a natural part of existence - can be helpful in preventing one from becoming overwhelmed when difficult situations arise. (Dalai Lama \& Cutler 1998:172)

But meditation on dukkha performs also other much more essential functions. Within the framework of Mahāyāna Buddhism, mysticism is seen chiefly as the path to getting fully in tune with reality by removing from one's consciousness all the filters. Awareness of suffering is to be conceived as a crucial means for such a purgation of consciousness, which of course has its practical consequences. From the existential and ethical point of view, reflecting on suffering has tremendous importance because by realising its nature, one can develop 'greater resolve to put an end to the causes of suffering and the unwholesome deeds which lead to suffering' (Dalai Lama \& Cutler 1998:172). The mystic has to be aware of $d u k k h a$, and even plunge into suffering in order to feel it deeply, as it is commonly known that 'happy people don't develop wisdom. They are asleep' (Chah 2005:58). If a human being does not analyse the fact of suffering, he or she will never understand it, no matter how many births he or she goes through. Whilst facing pain, one has a chance to enter the mystical path on which one may discover a way out of suffering. The pervasive unsatisfactoriness of existence dukkha itself - can be therefore seen as a 'noble truth' and, consequently, meditating on it constitutes the starting point of the Buddhist mystical practice.

In a broad sense, three types of meditation can be distinguished:

- concentration

- surrender

- self-emptying.

The first type is the outer directed formal 'technique'; the second type is the inner directed spontaneous 'experience'; and the third type constitutes the 'negative path' of detachment (Stevens 1973:16). ${ }^{11}$ Let us examine at closer range the last approach. The negative way of meditation works to "eliminate "rational consciousness" so that suprarational might emerge' (Stevens 1973:34); its quest is the one for self-transcendence. In fact, what underlies Buddhism from the very beginning (though it blossoms most fully in its Tantric version) is the intuition of the transformation of negative psycho-energies into positive ones, understood as the essence of liberating the mind from karmic contamination. It can be reflected on in correlation with what the Western tradition calls the 'path of the night' and which involves, so to say, treatment by means of poison.

The first of the three examples of the experience of suffering being integrated in the mystical path I would like to mention, namely the practice of Asubhabhāvanā, is based on this very principle. It can be summarised as a reflection on death, and even more, its 'anticipation'; that is, some kind of living death during one's own lifetime. The ascetic practices in which monks are required to arouse in themselves an aversion towards the body in a state of decay are known in many Oriental traditions, including the oldest forms of Buddhism. What does the practice itself look like? Asubhabhāvanā is a form of Yoga contemplation, consisting in meditating on the disgust evoked by a human corpse (Dïghanikāya III, 223). To come to realise the hideous and impermanent character of all corporeal being, a monk - often sitting in the middle of a crematory ground - is imagining dead bodies at different stages of decay and repeats: 'Truly, my body is of the same nature and it will end in the same way.'

The task of the 'meditation on the impurity of the body' is to recognise visually one of the three main characteristics

11.For the Christian understanding of the mystical 'theology of darkness', see Bailey (1975:102-106). For the comparison of Christian and Buddhist forms and meanings of via negativa, see Fredericks (1999:83-84). 
of any being, namely its impermanence or destructibility (anicca), and to develop in oneself a constant, unchangeable spiritual disposition to see the real nature of the world, namely dukkha. Thanks to such a change of perspective the follower of the negative path of meditation is better prepared to become independent of various external circumstances and to concentrate his or her mind on an arduous spiritual practice. In this way, one learns to say 'no' to the enslavement of thoughts and desires, so that one may say 'yes' to higher consciousness, to responsibility for one's own life, and to acceptance of one's imminent death (Stevens 1973:48). Therefore, the ultimate aim of asubhabhāvanā is not to arouse disgust for life, but to remove attachment, the will to live, and thus to gain serenity, peace and bliss.

As some claim, a 'deep realisation of the interconnectedness of everyone and everything' (Teasdale 1999:114) constitutes a basic aspect of mysticism as such. Some schools of Mahāyāna Buddhism made the ethical consequences of this ontological fact the actual fundament of their mystical approach. ${ }^{12}$ According to Tibetan Buddhism, being aware of suffering helps one to develop the capacity for empathy, 'to relate to other people's misery, and thus enhances one's capacity for compassion towards fellow beings' (Dalai Lama \& Cutler 1998:173). Therefore a bodhisattva resolves the following:

I take upon myself the burden of all suffering ... the burdens of all beings ... The whole world of living beings I must rescue, from the terrors of birth, of old age, of sickness, of death and rebirth ... I myself must grapple with the whole mass of suffering of all beings. (The Bodhisattva's Infinite Compassion, Vajradhvaha Sutra in Harvey 1996:76)

This is the idea that underlies the practice of Tong-len, the second example I want to briefly discuss referring to the Dalai Lama's teaching.

Tong-len [giving and receiving] can be described as a Mahāyāna visualisation practice 'in which one mentally visualizes taking on another's pain and suffering, and in turn giving them all of one's own resources' such as good health and fortune (Dalai Lama \& Cutler 1998:171); it is a kind of 'suffering by proxy' (Dalai Lama \& Cutler 1998:178):

May my suffering be a substitute for the suffering of all other sentient beings. By experiencing this, may I be able to save all other sentient beings who may have to undergo similar suffering. (Dalai Lama \& Cutler 1998:171)

This is the intention the monk is supposed to arouse in his mind. Practices such as Tong-len are based on the conviction that it is our suffering that is the most basic element that we share with others, the factor that unifies us with all living creatures' (Dalai Lama \& Cutler 1998:177). Tong-len meditation may have a very beneficial influence on one's spiritual practice. First of all, it helps counteract one's selfishness. Furthermore, it can make a significant difference

12.The Buddhists establish their entire religious praxis on the metaphysical perception of interconnectedness, which they call pratiya-samutpada [dependent perception of interconnectedness, which they call pratiya-samutpada [dependent origination]. The parallel intuition on the Christian side underlies the concept of
the Mystical Body of Christ, a community of believers rooted in and centred on Christ as their 'Head'. in how a suffering person responds to the situation of, for example, illness in terms of his or her mental attitude: instead of being overwhelmed by anxiety and worry, one may save oneself from additional mental (psychological) pain and anguish by adopting the right attitude and, in fact, even see one's miserable state as a kind of opportunity and privilege. In such a way, one's suffering 'takes on new meaning as it is used as the basis for a religious or spiritual practice' (Dalai Lama \& Cutler 1998:172).

It is particularly stressed in Zen Buddhism that most human beings are asleep, that is, deeply immersed in illusion, and that to attain enlightenment is, de facto, equivalent to being awoken and starting to live:

We all think we are living. We really eat, sleep, walk, talk. But are we really? If we were, we would never be talking about 'dread', 'insecurity', 'fear', 'frustration', 'courage to be', 'looking into the vacant', 'facing death'. (Suzuki 2002:30)

Zen Buddhism basically speaks of two decisive moments that mark the spiritual practice leading to liberation: entering the path and the moment of enlightenment itself. Of course, there is a place for training which, in a sense, prepares one to enlightenment, yet in no way can such training be considered a cause of enlightenment. Zen practice is presented, especially in the Lin-chi or Rinzai tradition, in a totally negative way: 'All it does is lead the trainee to a dead end of all his [or her] faculties, a thorough impotence or despair'; this is called The Great Doubt or The Great Death (Mommaers \& Van Bragt 1995:184-185). This is the third and final illustration of suffering's positive meaning within the Buddhist mystical traditions. Enlightenment, seen as a Great Light, a Great Life, or Resurrection, cannot break through but from this very point. Zen texts often describe the dialectic of The Great Death and The Great Life. It comes to full force in the words of the Zen master Yüan-wu (1063-1135) who is talking about 'coming across a light in thick darkness' or 'receiving treasure in poverty' (Merton 1980:233). The meaning of The Great Death can also be grasped with the help of the following Zen story:

A disciple came to his master and asked, 'It is terribly hot, and how shall we escape the heat?' And at once the answer came, 'Let us go down to the bottom of the furnace'. So the perplexed disciple asked again, 'But in the furnace how shall we escape the scorching fire?' To which he received the surprising reply, 'There, no further pains will harass you'.13 (Harvey 1996:84)

\section{Passio overcome by Visio}

It is time to pose the question whether Christian mysticism is tantamount to masochism or not. Many scholars, particularly in the West, see the practice of mysticism in general and Christian mysticism in particular as basically masochistic (Berger 1961; Douglas 1970). They consider the self-denial, the withdrawal, and the disappearance of the

13.For the sake of precision, it has to be clarified that The Great Death is not tantamount to the experience of suffering per se. The experience in question is to be conceived ather in terms of emptiness and purity than actual pain. It implies the experience sought to its summit, allows the delusion to be cut off and a new life to arise. Nonetheless, this experience may be considered as related to the reality of suffering, in its broad (e.g. Eckhartian) sense. 
individual to be anti-human. Thus they question the role of mysticism as a means of self-realisation, reproaching it for being, instead, a way of self-destruction: a pathology which refuses to affirm and develop the self and a symptom of social alienation. In such a context, the mystic appears as a potential rebel, masochist, and a social outcast (Stevens 1973:161-163). But can the self-emptying, purifying process of mysticism (the negative way) really be conceived as a type of physical and psychological suicide (Stevens 1973:168)?

Apart from obvious perversions of physical discipline sometimes turned into pure masochism, the Christian ideal of ascetic life has often been misunderstood and misrepresented, especially with regard to the meaning and intention lying behind ascetic practices. They are not intended as punishment or rejection of the natural order, but rather as a means for the 'subduing of the passions and the control of the senses' (Bailey 1975:78) which serves, in turn, the purpose of 'clearing away the barriers to the experience of the goodness of creation' (Bailey 1975:78), of continuing the 'work of re-creation begun in, by, and through Christ' (Bailey 1975:78), and finally of 'the death of the old for the sake of giving birth to the new' (Bailey 1975:78). In short, voluntary suffering is for Christian mystics a means of catharsis and metanoia. In this sense, Teresa of Avila exhorted her spiritual charges to 'spin a cocoon of death for the silkworm that the new creature of beauty might emerge' (Bailey 1975:79). ${ }^{14}$ Let us now retrace at least some of the mystical testimonies alluded to earlier.

Julian of Norwich, whose 'showings' have been briefly discussed above, does not desire bodily pain for itself. Far from that, she has an appreciation of the suffering body only as the seat of real love: ${ }^{15}$ a love that 'unites with the human person [of Jesus] and at once leads to the divine' (Mommaers 2003:48). In the ninth Revelation, we see the divine emerge from the most miserable human and joy emerge from suffering. Thus the seeing of the visionary coincides with the mystic's own transformation: '[T] he changing of his blessed expression changed mine', Julian admits, 'our Lord made me think happily, " $[w]$ here is there now one jot of your pain or your sorrow?"' (Colledge \& Walsh 1978:379).

\section{In the same spirit, Meister Eckhart claims:}

If you suffer for God's sake and for God alone, that suffering does not hurt and is not hard to bear, for God takes the burden of it ... What one suffers through God and for God alone is made sweet and easy. (Suzuki 2002:136)

In another place, the Dominican mystic underscores the role that the 'spiritual desert' plays in achieving unio mystica:

The spirit seeks to be broken through by God. God leads this spirit into a desert, into the wilderness and solitude of the divinity where God is pure unity and where God gushes up within himself. (Harvey 1996:191)

14. Also Meister Eckhart has stressed the importance of the 'annihilation' of self: 'I say that if the soul is to know God, it must forget itself ... for as long as it is self-aware and self-conscious, it will not see or be conscious of God' (Blakney 1957:131).

15.'I wanted his pains to be my pains, with compassion, and then longing for God' (Colledge \& Walsh 1978:292 [author's emphasis])
Bernard of Clairvaux (1971:51-52) bases his description of contemplation on two pivotal terms, namely 'death' and 'rest', whilst the former refers to the liberation from the restlessness that holds those still alive, the latter, synonymous with sleep, points to the state of the contemplative who, like the bride, 'sweetly sleeps within the arms of her bridegroom, in ecstasy of spirit'.

In the case of Francis of Assisi, the means and the ultimate aim of the transformation through suffering is, again, love, 'the fire of ecstatic love', as Bonaventure (1978:263), the biographer of Povorello, puts it. ${ }^{16}$ And, like in the case of Bernard, the final word belongs not to bodily pain, but to saving grace, because, according to Bonaventure, in the last analysis, Francis was transformed 'not by the martyrdom of his flesh, but by the fire of his love consuming his soul' (Bonaventure 1978:306). ${ }^{17}$ The revelation of paradise made by Christ to the good thief has also been made to Francis of Assisi and, in a broader sense, to many other mystics. In their case, however, 'paradise' has been realised already in this life by way of Christ-centred ecstasy (Mommaers 2003:156). This mystical experience allowed Francis to admit that it is in dying to self that we are born to eternal life' (Harvey 1996:193). Only someone gifted with unusual internal freedom could address God with the following words of praise:

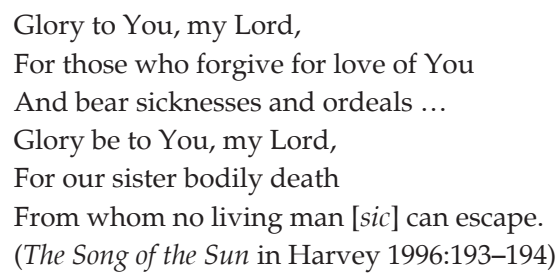

Reading the works of Teresa of Avila, one may conclude that she was almost obsessed with the desire to suffer together with Jesus. But again, her willingness to participate in the Saviour's passion is to be seen as a means for union with God. For instance, the imaginative visions of the suffering Christ-the-bridegroom and spiritual marriage, conceived as taking part in his death and resurrection, led Teresa to a more intellectual vision of the Trinity that brought her into the seventh Mansion (Peers 1946:334, 331-332). But also the other way round: Teresa (Mommaers 2003:94) admits that 'the divine impression is such that it causes its human expression', that is to say, the deeply spiritual impulse initiates an 'interior movement that proceeds from the centre of the soul and awakens the faculties'. And what the human powers are so strongly urged to do is precisely to serve and to suffer in the way that Jesus himself did. As Teresa writes, 'these favours [perfect contemplation] are given us to strengthen our weakness ... so that we may be able to imitate Him [Jesus] in his great sufferings (Peers 1946:345). For the Saint of Avila, the mystical experience of fellow-passion with Jesus is also a call to service: 'Do you know when people really become spiritual?' (Peers 1946:346) - she asks in her El Castillo Interior:

16.The climax of this experience is to be found in the 'ecstatic contemplation' of Francis on Mount Alverna (Bonaventure 1978:263).

17.According to the different translation, '... through complete conflagration of mind' (McGinn 2006:229) 
It is when they become the slaves of God and are branded with his sign, which is the sign of the Cross ... Then He can sell them as slaves to the whole world, as He Himself was sold. (Peers 1946:346)

Thomas Merton was also aware that in daring to embrace our own demons, we may discover our own truth and divinity (Stevens 1973:53). Thus in New seeds of contemplation (2007), he states that 'prayer and love are really learned in the hour when prayer becomes impossible, and the heart turns to stone' (Merton 2007:221). That is also the hour that presents a real challenge to the negative path of detachment, disidentification, and the entry into darkness (Stevens 1973:37). Merton reminds us that a genuine contemplation is 'at the same time the source and result of crisis' (Bailey 1975:104, 125). And yet one also has to remember that monastic discipline, including all sorts of mortification, has only one purpose, namely to emancipate the monk. It is 'utterly useless', Merton (1967:94) points out, 'if it turns us into freaks'. Therefore, on the one hand, misery and destitution as such cannot be treated as the way to contemplative union (Bancroft 1989:37). Yet, on the other hand, to deny oneself and taking up one's cross to follow Christ (cf. Mk 8:34) is a necessary condition of mystical union with God. Visio beatifica appears, then, not as a compensation, but as a result of suffering, yet - it has to be added - of suffering experienced as meaningful through one's union with Christ (Bailey 1975:176).

To sum up what has been said so far, a critical caveat must be made. In the experience of Christian mystics, suffering - both with regard to Jesus and to mystics themselves - always appears as an intermediary stage, as an expression of unconditional trust in God and resulting love, as a step on the way leading to transformation. That step, however, cannot easily be dismissed, as on inner-Christian grounds the Cross constitutes a sine qua non condition of salvation (Mommaers 2003:55). As Mommaers (2003:57) says, the 'imaginative and affective concentration of the senses upon a senselessly suffering and destroyed human figure [of Jesus]', to the point of participating in his suffering, is for the majority of mystics 'the only possible way to be personally touched in the spirit ... by indestructible joy, life, love, and the imageless Reality'. Thus suffering, in its broad sense, appears in the Christian mystical traditions not only as a component of the via purgativa; it can be also seen as a 'special gift' from God allowing the mystic to unite even closer with the suffering Christ, as a fruit of an intimate love between creature and Creator.

This 'paradox of the darkness born of light' - to use Bailey's (1975:104) phrase - 'is one of the religious experiences attested to by almost all of those who have earned a place of honour in the mystical tradition'. However, in the last analysis, humanity is saved not by suffering per se, but by faith and love, of which suffering is an inevitable correlate. Christian mystics are aware of that truth and give it various expressions, some of which have been mentioned above. The fact that it is fides and caritas rather than passio in itself - be it Christ's or ours - which informs Christian soteriology is thus confirmed by the mystical traditions of Christianity, whilst at the same time all of them emphasise, to a greater or lesser extent, that visio beatifica is not possible without one's personal participation in passio Christi.

\section{Conclusion}

Even though Buddhism and Christianity start from different points (the first from a certain empirical statement and the second from revealed truth) ${ }_{1}^{18}$ they can meet each other in the two important aspects of their respective approaches to suffering:

- Firstly, they agree that suffering is 'part of our very egoidentity and empirical existence' (Merton 1995:41).

- Secondly, they profess a readiness and wish to carry the human person through the abyss of suffering to the other shore (of nirvana or eternal life), in which they exhibit their common, explicitly soteriological character.

Both these facets can be clearly captured in the mystical traditions of Buddhism and Christianity, as rich and diverse as they are.

\section{As Thomas Merton (1980) points out:}

While on the level of philosophical and doctrinal formulations there may be tremendous obstacles to meet, it is often possible to come to a very frank, simple, and totally satisfying understanding in comparing notes on the contemplative life, its disciplines, its vagaries, and its rewards. (p. 209)

In many regards (the question of suffering being just one of many cases in point), it seems that what rationality cannot grasp can be touched by concrete mystical experience (Stevens 1973:97). The Buddhist-Christian dialogue, when carried out on the level of doctrine and theology, often proves fraught with formidable difficulties. But when it moves onto the mystical level, it turns out to be very fruitful and mutually stimulating. Indeed, it can be said that the central role in this dialogue is played by mysticism. ${ }^{19}$

This study at once stems from and promotes a balanced view of mystical experience as bounded, yet not limited, by particular religious traditions in terms of its means of expression and hermeneutics thereof. As a consequence - to refer to the famous Kantian distinction - mystical appropriations of the Buddhist and Christian understandings of suffering offer certain boundaries (Schranken) to interfaith dialogue, but they do so without imposing limits (Grenzen) on it (Kant [1781] 2002:142). In other words, they allow both Buddhism and Christianity to preserve their particular genii whilst analogically reaching out to the hard concreteness of the other (Tracy 1981:452).

18.It is important to stress that the contrast mentioned above is not absolute: there is an empirical element in the Judeo-Christian tradition and a revelatory element in some forms of Buddhism; for example, the biblical wisdom tradition, which has shaped much of the teaching of Jesus, begins with empirical reality, whereas Mahāyāna Buddhists who venerate the Trikaya [three bodies] believe that the Mahayana Buddhists who venerate the Trikaya [three bodies] believe that the unmanifested and inconceivable aspect of a Buddha].

19. Buddhists engaged in the dialogue with Christianity spontaneously focus on Christian mysticism. They willingly refer to Francis of Assisi and to the Spanish mystics, Teresa of Avila and John of the Cross, but 'the lion's share of their attention clearly goes to the "metaphysical mysticism" of Meister Eckhart' (Mommaers \& Van Bragt 1995:30). 
In this article, it has been shown that the meanings ascribed to suffering by the mystical traditions of Buddhism and Christianity cannot be reduced to the simplistic discrepancy epitomised by the figures of 'sage-the-robot', absolutely detached from any human hardship, and 'saintthe-sufferer', masochistically plunging into suffering. Those two opposed tendencies are indeed reflected by the Buddhist view that ultimately every suffering is illusionary as it lacks in sufferer and the Christian understanding that following Christ by taking up one's personal cross is the only way of achieving perfect communion with God. However, a thorough examination of the roles that suffering plays in the mystical traditions of Buddhism and Christianity discloses a much more nuanced picture in which Buddhist dukkha itself appears as a transformative aspect of the Dharma and Christian passio as being transcended by faith and love and definitively overcome for the sake of the beatific vision of God.

This article has been written from a theological-philosophical perspective, not a historical one. Doing justice to the latter would require producing a vast volume or, alternatively, a radical narrowing down of the topic to the detriment of the holistic view - the panorama, one might say - of the meanings of suffering in the mystical traditions of Buddhism and Christianity. My hope is that by dealing with the broad notions of Buddhist and Christian mysticisms, this study may provide a basis for the development of the theoretical framework for subsequent, more historically-grounded projects that could entail an assessment of the political, economic, and gender roles of mystical individuals and groups as they deal with both the experience and the topic of suffering.

For both Buddhists and Christians, the human predicament poses much more than a purely intellectual challenge; suffering challenges the very experiential core of the two religions in question. And yet ultimately these two dimensions - doctrinal and mystical - cannot be artificially separated: only by being 'equipped' with meaning (be it didactic, transformative or salvific), can suffering be positively embraced in one's spiritual journey. Let me conclude my reflection with the words of Thomas Merton (1995):

It would be a grave error to suppose that Buddhism and Christianity merely offer various explanations of suffering, or worse, justifications and mystifications built on this ineluctable fact ... Suffering, as both Buddhism and Christianity see, each in its own way, is part of our very ego-identity and empirical existence, and the only thing to do about it is to plunge right into the middle of contradiction and confusion in order to be transformed by what Zen calls the 'Great Death' and Christianity calls 'dying and rising with Christ'. (p. 41)

\section{Acknowledgments}

I would like to thank Dr Nontando Hadebe who has introduced me to the spiritual treasures of African culture and has blessed me with her ongoing friendship and support since I arrived in South Africa.

\section{Competing interests}

The author declares that he has no financial or personal relationship(s) that may have inappropriately influenced him in writing this article.'

\section{References}

Bailey, R., 1975, Thomas Merton on mysticism, Image Books, New York.

Bancroft, A., 1989, Twentieth-century mystics and sages, Arkana, New York.

Berger, P., 1961, The precarious vision: A sociologist looks at social fictions and Christian faith, Doubleday and Company, Inc., New York.

Bernard of Clairvaux, 1971, On the song of songs I, transl. K.J. Walsh, Cistercian Publications, Spencer.

Blakney, R.B., 1957, Meister Eckhart: A modern translation, Harper \& Brothers, New York.

Bodhi, B., 2005, In the Buddha's words: An anthology of discourses from the Pali Canon, Wisdom Publications, Boston.

Bonaventure, 1978, The soul's journey into God: The tree of life. The life of St. Francis, transl. E.H. Cousins, Paulist Press, New York.

Chah, A., 2005, Everything arises, everything falls away: Teachings on impermanence and the end of suffering, transl. P. Breiter, Shambhala Publications, Boston.

Cioran, E., 1970, The fall into time, transl. R. Howard, Quadrangle Books, Chicago.

Colledge, E. \& Walsh, J. (eds.), 1978, A book of showings to the anchoress Julian of Norwich, Pontifical Institute of Mediaeval Studies, Toronto.

Dalai Lama \& Cutler, H.C., 1998, The art of happiness: A handbook for living, Hodder \& Stoughton, London.

Davies, O., 1991, Meister Eckhart: Mystical theologian, SPCK, London.

Douglas, M., 1970, Natural symbols: Explorations in cosmology, The Cressett Press, London.

Frankl, V., 1967, Psychotherapy and existentialism: Selected papers on logotherapy Simon and Schuster, New York.

Fredericks, J.L., 1999, Faith among faiths: Christian theology and the non-Christian religions, Paulist Press, Mahwah.

Gyatso, P.R.J.T.T., 1994, Liberation in our hands. Part Two: The fundamentals, ed. Y. Gyatso, transl. S. Tharchin \& A.B. Engle, Mahayana Sutra and Tantra Press, Howell. Harmless, W., 2008, Mystics, Oxford University Press, Oxford.

Harvey, A., 1996, The essential mystics: Selections from the world's great wisdom traditions, Harper San Francisco, New York.

Hubbard, J. \& Swanson, P.L. (eds.), 1997, Pruning the Bodhi Tree: The storm over critical Buddhism, University of Hawaii Press, Honolulu.

Kant, I., [1781] 2002, Theoretical philosophy after 1781, ed. H.E. Allison, P.L. Heath, transl. G.C. Hatfield, M. Friedman, H.E. Allison, P.L. Heath, Cambridge University Press, Cambridge [ebook].

Küng, H., Van Ess, J., Von Stietencron, H. \& Bechert, H., 1986, Christianity and world religions: Paths of dialogue with Islam, Hinduism, and Buddhism, transl. P. Heinegg, Doubleday, Garden City.

Marcel, G., 1949, Being and having, transl. K. Farrer, Dacre Press, Westminster.

McGinn, B. (ed.), 2006, The essential writings of Christian mysticism, The Modern Library, New York.

McGinn, B., 1996, The growth of mysticism: Gregory the Great through the 12th Century, Herder \& Herder, New York.

Merton, T., 1967, No man is an island, Image Books, Garden City.

Merton, T., 1980, Mystics and Zen masters, Dell Publishing Co., New York.

Merton, T., 1995, Thoughts on the East, New Directions Bibelot, New York.

Merton, T., 2007, New seeds of contemplation, New Directions Publishing, New York.

Mommaers, P. \& Van Bragt, J., 1995, Mysticism Buddhist and Christian. Encounters with Jan van Ruusbroec, Crossroad, New York.

Mommaers, P., 2003, The riddle of Christian mystical experience: The role of the humanity of Jesus, Peeters Press, Louvain.

Monk Damascene n.d., 'Blessed Hieromonk Seraphim Rose", in Death to the world viewed 11 April 2014, from http://deathtotheworld.com/articles/blessedhieromonk-seraphim-rose/

Peers, E.A., 1946, Complete works St. Teresa of Avila [Interior Castle], Sheed and Ward, London.

Routledge encyclopaedia of philosophy, 1998, s.v. 'Mysticism', in E. Craig (ed.) Routledge, London, p. 620.

Stevens, E., 1973, An introduction to oriental mysticism, Paulist Press, New York.

Suzuki, D.T., 2002, Mysticism: Christian and Buddhist, Routledge Classics, London/New York.

Teasdale, W., 1999, The mystic heart: Discovering a universal spirituality in the world's religions, New World Library, Novato.

Teresa of Avila, 1957, The life of Saint Teresa of Avila by herself, transl. J.M. Cohen, Penguin Books, London.

Tracy, D., 1981, The analogical imagination: Christian theology and the culture of pluralism, Peeters Press, Louvain. 